\title{
REFERENCES
}

Accessory Food Factors Committee of the Modical Research .Council (1843). Biochem. J. 87, 433.

Allen, R. J. L. (1940). Biochem. J. 84, 858.

Bauer, E. (1935). Naturwissenschaften, 51, 866. (1936). Hoppe-Seyl. Z. 239, 195.

Berenblum, I. \& Chain, E. (1938). Biochem. J. 32, 295.

Berliner, E. \& Rüter, R. (1928). Z. ges. Mühlenw. 4, 29.

Bodansky, A. (1932). J. biol. Chem. 99, 197. (1933). J. biol. Chem. 101, 93.

Collatz, F. A. \& Bailey; G. H. (1921). Industr. Engng Chem. $18,337$.

Folin, O. \& Ciocalteu, F. (1929). J. biol. Chem. 73, 627.

Folley, S. J. \& Kay, H. D. (1936). Ergebn. Enzymforsch. $5,189$.

Giri, K. V. (1936). Curr. Sci. 4, 833.

(1941). Ann. Biochem. exp. Med. 1, 297.

Gomori, G. (1939). Proc. Soc. exp. Biol., N.Y., 42, 23.

Gutman, A. B. \& Gutman, E. B. (1938a). Proc. Soc. exp. Biol., N.Y., 88, 470.

(1938b). J. clin. Invest. 17, 473.

(1940). J. biol. Chem. 186, 201.
Herd, C. W. (1931). Cereal Chem. 8, 145.

Hilbe, J. J. \& Marron, T. V. (1940). Proc. Iowa Acad. Sci. 47, 235.

Ignatieff, V. \& Wasteneys, H. (1936). Biochem. J. 30, 1171. King, E. J. \& Armstrong, A. R. (1934). Canad. med. As8. J. 81, 376.

'Lüers, H. \& Malsch, L. (1929). Wschr. Brau. 46, 143.

Mounfield, J. D. (1936). Biochem. J. 30, 549.

Munemura, S. (1933). J. Biochem., Tokyo, 17, 343.

Nemec, A. (1928). Biochem. Z. 202, 229.

Pringle, W. J. S. (1943). Private communication.

Sarma, M. L. \& Giri, K. V. (1942). Ann. Biochem. exp. Med. $2,17$.

Scharer, H. (1938). J. Dairy Sci. 21, 21.

Suzuki, V., Yoshimura, K. \& Takaishi, M. V. (1907). Tokyo Imp. Univ. Coll. Agric. Bull. 1, 503.

Takahashi, H. (1932). J. Biochem., Tokyo, 16, 447.

Uzawa, T. (1932). J. Biochem., Tokyo, 15, 1.

Weisselberg, F. (1931). Quoted by Feigl, F. (1937). Qualitative Analysis by Spot Tests. New York: Nordemann Publishing Co.

\section{Studies on Diffusing Factors}

\section{THE ACTION OF REDUCING AGENTS ON HYALURONIC ACID AND OTHER POLYSACCHARIDES}

\author{
By C. W. HALE, The Lister Institute of Preventive Medicine, Elstree, Herts
}

\author{
(Received 19 February 19A4)
}

Robertson, Ropes \& Bauer (1940) suggested that the spontaneous loss of viscosity of vitreous humour might be due to its high ascorbic acid content. McClean \& Hale (1940) showed that ascorbic acid, with or without hydrogen peroxide, increased dermal permeability and lowered the viscosity of hyaluronic acid. Thiolacetic acid, quinol, pyrogallol, 'metol', sodium sulphite and hydrogen sulphide caused a fall in the viscosity of hyaluronic acid; this fall was not immediate but progressed over a period (McClean \& Hale, 1941). Activation of an enzyme present in the hyaluronic acid solution was excluded by preheating the solution. No reducing sugar could be detected in the substrate after its viscosity had been lowered by reducing agents, as it can after hydrolysis by hyaluronidase.

Robertson, Ropes \& Bauer (1941) showed that the viscosity of other polysaccharides, such as starch and pectin, also could be decreased by reducing agents; not all organic reducing agents were equally effective, and the presence of hydrogen peroxide appeared to be necessary, since the effect was in- hibited by catalase. When their viscosity was decreased in this way the polysaccharides were no longer precipitable as asbestos-like clots. It was suggested that the change of viscosity might be due to a dephosphorylation of the viscous polysaccharide. Pirie (1942) showed that hyaluronic acid obtained from tumours contained copper, that the action of ascorbic acid on hyaluronic acid was catalyzed by copper, and that this could be inhibited by sodium diethyldithiocarbamate.

The present work was undertaken to investigate the action of reducing agents on hyaluronate and other polysaccharides and the part played by copper.

\section{RESULTS}

Sodium sulphate and oxidized thiolacetic acid or the oxidation products of ascorbic acid (all $0.01 \mathrm{M}$ solutions) do not lower the viscosity of the hyaluronate (Table ${ }^{*}$ ). Thus it may be presumed that the progressive lowering of viscosity referred to above depends upon the presence of an active reducing agent and not upon alterations in the salt content. 
Table 1. Influence of several solutions on the viscosity of hyaluronate

Solution

(1 vol. solution +5 vol. $0 \cdot 25 \%$

buffered hyaluronate)

$0.01 \mathrm{~m}-\mathrm{Na}_{2} \mathrm{SO}_{3}$

$0.01 \mathrm{M}-\mathrm{Na}_{2} \mathrm{SO}_{4}$

$0.01 \mathrm{M}$-cysteine

Saturated $l$-cystine

0.01 M-thiolacetate

$0.01 \mathrm{M}$-thiolacetate oxidized

in air until it would not reduce $\mathrm{FeCl}_{3}$

0.01 M-ascorbic acid

0.01 M-ascorbic acid oxidized

in air until it would not

reduce indophenol in $5 \%$

trichloroacetic acid

The rate of degradation* is not influenced by the concentration of selts present which is known to affect the activity of hyaluronidase (McClean \& Hale, 1941 ; Madinaveitia \& Quibell, 1941 ; McClean, 1943).

Effect of ascorbic acid on the viscosity of starch, pig gastric 'mucin' and gelatin compared with that on hyaluronate. Confirming Robertson et al. (1941), it has been found that ascorbic acid and other reducing agents lower the viscosity and destroy the characteristic precipitability of other polysaccharides besides hyaluronic acid, e.g. starch paste and 'mucin' not dialyzable through a cellophan membrane, and that after the action of reducing agents starch still

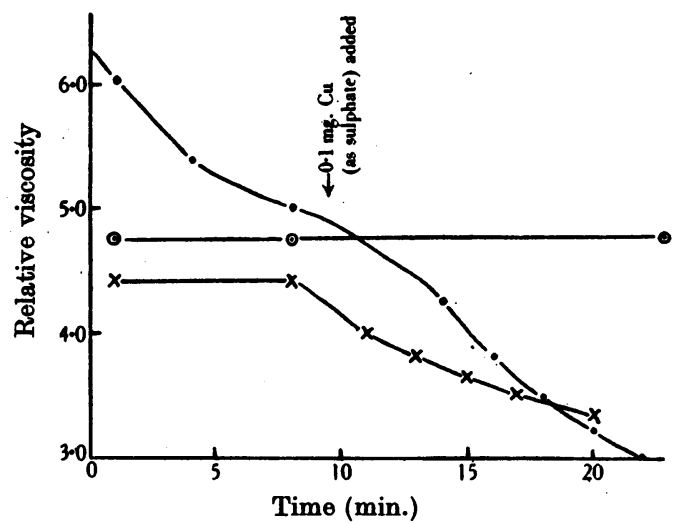

Fig. 1. Influence of ascorbic acid and $\mathrm{Cu}$ on the viscosity of starch, gelatin and 'mucin' from pig gastric mucosa. $2.5 \mathrm{ml}$. solution of polysaccharide or protein and $0.5 \mathrm{ml}$. ascorbic acid (final concentration $0.01 \mathrm{M}$ ), $\mathrm{pH} 7 \cdot 0$. $\bullet$ Potato starch 6 mg./35 ml. $\bigcirc-\odot$ Gelatin, $1 \%$. $x-x$ 'Mucin' from pig gastric mucosa (Wilson, Type 1701-W) $0.5 \%$.

gave an unmodified iodine reaction (Table 2). There was no evidence of liberation of $N$-acetylglucosamine from hyaluronate, nor was the degraded hyaluronate

\section{Table 2. Action of ascorbic acid on hyaluronate and potato starch}

( $0.5 \mathrm{mg}$. Cu (as sulphate) and chloroform to saturate, added to each sample. Mixtures each contained in cellophan tube suspended in $20 \mathrm{ml}$. of water at $4^{\circ}$ for $48 \mathrm{hr}$. Hydrolysis with 100 v.R. units (McClean, 1943) of Cl. welchii hyaluronidase for $6 \mathrm{hr}$. at $37^{\circ}$.)

\begin{tabular}{|c|c|c|c|c|c|c|c|c|}
\hline \multicolumn{3}{|c|}{ Mixtures } & \multicolumn{5}{|c|}{ Results after dialysis } & \multirow{2}{*}{$\begin{array}{c}\text { Results after } \\
\text { hydrolysis with } \\
C l \text {. welchii } \\
\text { hyaluronidase. } \\
N \text {-Acetyl } \\
\text { glucosamine }\end{array}$} \\
\hline $\begin{array}{l}\text { Potato } \\
\text { starch } \\
(6 \mathrm{mg} . / \\
35 \mathrm{ml} .) \\
\text { (ml.) }\end{array}$ & $\begin{array}{c}\text { Hyal- } \\
\text { uronate } \\
(0 \cdot 25 \%) \\
(\mathrm{ml} .)\end{array}$ & $\begin{array}{l}\text { Ascorbic } \\
\text { acid }\end{array}$ & & Viscosity & $\begin{array}{l}\text { Action of } 20 \mathrm{vol} . \\
\text { ethanol or } \\
\text { acetone }\end{array}$ & $\begin{array}{l}\text { Iodine } \\
\text { reaction }\end{array}$ & $\begin{array}{l}N \text {-Acetyl } \\
\text { gluco- } \\
\text { samine }\end{array}$ & \\
\hline 10 & 一 & $\mathbf{M} / \mathbf{6 0 0}$ & $\begin{array}{l}\text { Diffusate } \\
\text { Dialysate }\end{array}$ & Decreased & No precipitate & $\begin{array}{l}\text { Negative } \\
\text { Positive }\end{array}$ & - & - \\
\hline - & 10 & $\mathbf{M} / 600$ & $\begin{array}{l}\text { Diffusate } \\
\text { Dialysate }\end{array}$ & Decreased & No precipitate & E & $\begin{array}{l}\text { Negative } \\
\text { Negative }\end{array}$ & $\begin{array}{l}\text { Nil } \\
\text { Strong reaction }\end{array}$ \\
\hline 10 & - & - & $\begin{array}{l}\text { Diffusate } \\
\text { Dialysate }\end{array}$ & Not decreased & $\begin{array}{l}\text { Flocculent } \\
\text { precipitate }\end{array}$ & $\begin{array}{l}\text { Negative } \\
\text { Positive }\end{array}$ & - & - \\
\hline - & 10 & - & $\begin{array}{l}\text { Diffusate } \\
\text { Dialysate }\end{array}$ & Not decreased & Mucin clot & - & $\begin{array}{l}\text { Negative } \\
\text { Negative }\end{array}$ & $\begin{array}{l}\text { Nil } \\
\text { Strong reaction }\end{array}$ \\
\hline
\end{tabular}

from pig gastric mucosa (Fig. 1). The viscosity of gelatin is not altered. It was found that the products after the degradation of hyaluronate or starch were

*. In this paper the term 'degradation' means that the polysaccharides suffer an irreversible change from their naturally occurring physical condition and does not necessarily imply that any measurable chemical change has taken place. Evidence that the macromolecules of the viscous polysaccharides undergo disruption to smaller units is provided by a marked fall in viscosity and loss of precipitability from mixtures of organic solvents and water. precipitated from aqueoús solution by any concentration of ethanol or acetone up to $95 \%$ by volume. Enzymic hydrolysis of either starch or hyalurohate after degradation by ascorbic acid + $\mathrm{Cu}$ is slower than that of the unchanged polysaccharides. Seshagirirao \& Giri (1942) reported the reduction in the rate of hydrolysis by amylolase and J. H. Humphrey has observed (personal communication) a similar result with hyaluronidase.

Influence of oxygen and of reduced oxidationreduction $(\mathrm{O} / \mathrm{R})$ dyes on hyaluronate. The following 
dyes in the reduced form $(0.01 \mathrm{M}, \mathrm{pH} \mathrm{7.0)}$ did not lower the viscosity of hyaluronate with nitrogen as gas-phase: methylene blue, $\mathrm{K}$-indigo tetrasulphonate, $\mathbf{K}$-indigo trisulphonate, $\mathbf{K}$-indigo disulphonate, phenosafranine, rosinduline and neutral red.
Influence of hydrogen peroxide. Robertson et al. (1941) reported that addition of hydrogen peroxide to an ascorbic acid + hyaluronate mixture caused a 250-fold acceleration in the rate of loss of its characteristic precipitability, but McClean \& Hale (1941),

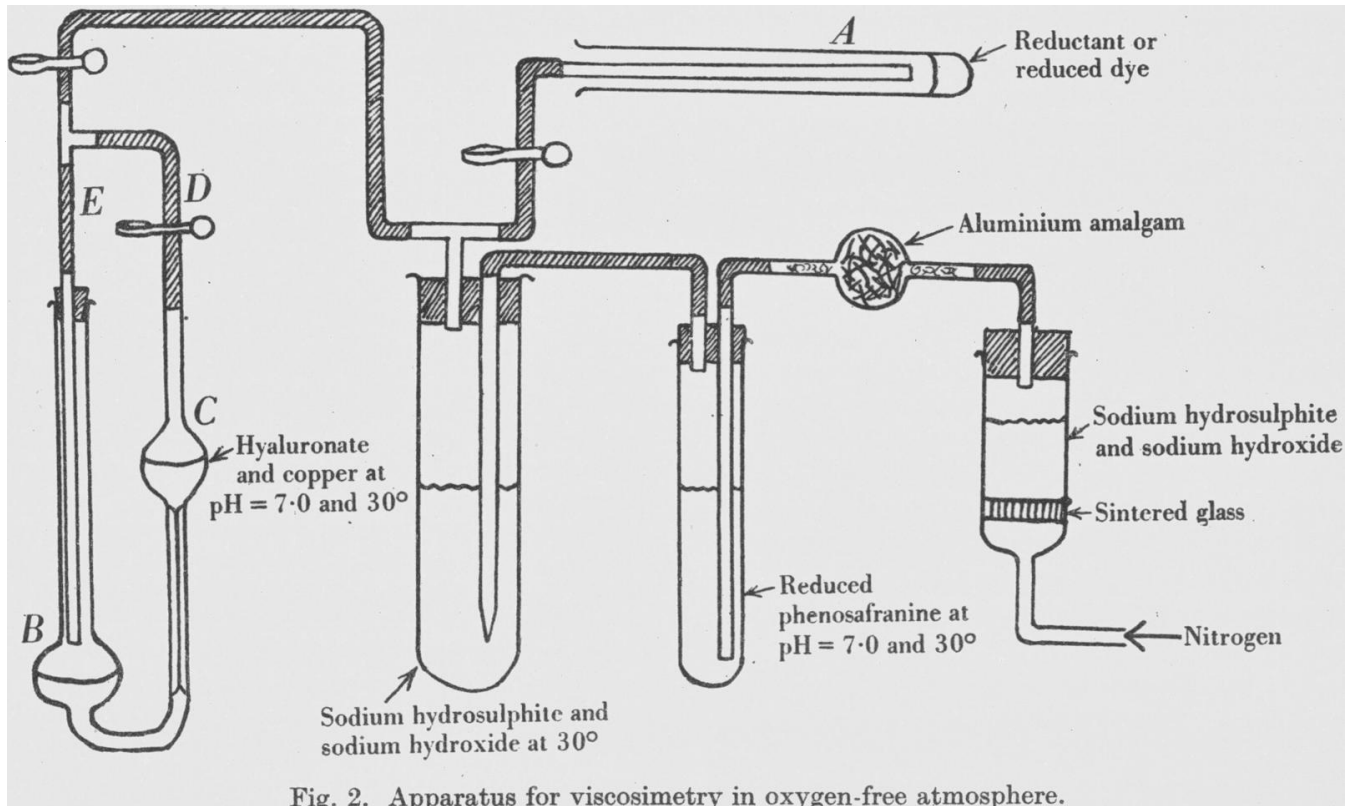

When ascorbic acid $(0.01 \mathrm{~m}, \mathrm{pH} 7.0)$ was used in place of the dyes there was an initial slight fall in viscosity which was thereafter negligible until air was admitted, when the fall became rapid (Fig. 3).

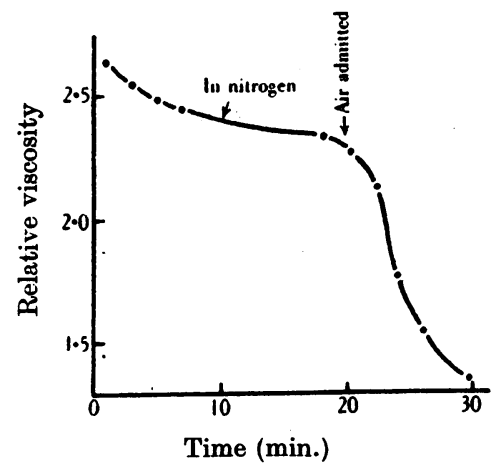

Fig. 3. Influence of oxygen on the viscosity of hyaluronate in the presence of ascorbic acid. $2.5 \mathrm{ml}$. buffered hyaluronate $(0.25 \%)$ (pH 7.0). $0.5 \mathrm{ml}$. ascorbic acid (0.01 M).

With reduced phenosafranine the same result was observed on admitting oxygen. This need for oxygen partially explains the gradual nature of the degradation of the hyaluronate, since the rate will be affected by the accessibility of oxygen. using a viscosimetric technique, found very little difference in the rate whether hydrogen peroxide was present or not. According to Barron, DeMeio

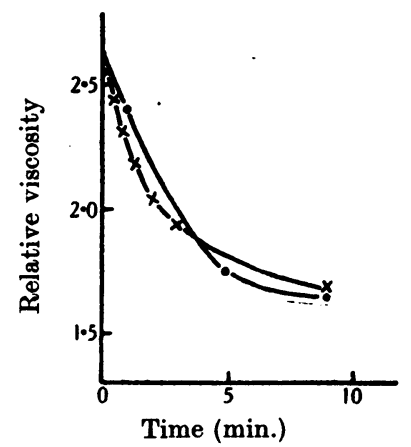

Fig. 4. Influence of catalase on the fall in viscosity of hyaluronate in the presence of ascorbic acid. - Water (1 vol.) + ascorbic acid + Cu + hyaluronate (11 vol.). $\times-\times$ Catalase (1 vol. $)+$ ascorbic acid + $\mathrm{Cu}+$ hyaluronate (11 vol.). The catalase was still active at the end of the experiment.

\& Klemperer (1935), hydrogen peroxide is formed during the catalytic oxidation of ascorbic acid by copper. Robertson et al. (1941) accordingly suggested that the degradation of hyaluronate by 
ascorbic acid + copper might be due to hydrogen peroxide formation and reported that addition of catalase completely inhibited the degradation. We find that the addition of rabbit liver catalase to an ascorbic acid $+\mathrm{Cu}+$ hyaluronate mixture does not influence the rate of decrease of viscosity (Fig. 4). Furthermore, in an ascorbic acid + hyaluronate mixture to which excess hydrogen peroxide had been added, the addition of sodium diethyldithiocarbamate causes a marked decrease in the rate of lowering of viscosity whereas. cupric sulphate accelerates it (Fig. 5). Since catalase did not inhibit this lowering

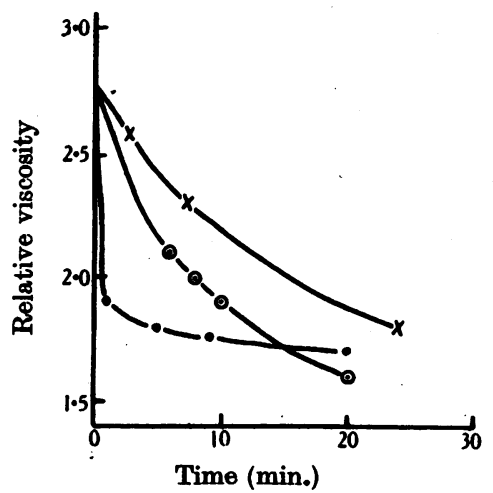

Fig. 5. Influence of $\mathrm{Cu}$ and $\mathrm{Na}$ diethyldithiocarbamate on the fall of viscosity of hyaluronate in the presence of ascorbic acid and excess $\mathrm{H}_{2} \mathrm{O}_{2}$. $2.5 \mathrm{ml}$. buffered hyaluronate and $0.5 \mathrm{ml}$. of a mixture of $1 \mathrm{vol} .0 .01 \mathrm{M}$-ascorbic acid with 1 vol. $6 \% \mathrm{H}_{2} \mathrm{O}_{2}$. $\bullet 0.1 \mathrm{mg}$. Cu (as sulphate) added. $\times-\times 1.0 \mathrm{mg}$. Na diethyldithiocarbamate added. $\odot-\odot$ Nothing added.

of viscosity, hydrogen peroxide is apparently not essential. The inhibitory action of sodium diethyldithiocarbamate in the presence of excess hydrogen peroxide then indicates that the catalytic action of copper is due to some function other than the provision of hydrogen peroxide.

Influence of copper. Confirming. Pirie (1942), we have found that the addition of cupric sulphate to an ascorbic acid +hyalurónate mixture increases the rate of degradation whereas the addition of sodium diethyldithiocarbamate inhibits the reaction. Sodium diethyldithiocarbamate similarly inhibited the catalytic action of copper upon the lowering of viscosity by cysteine or sodium sulphite. Even as much as $1 \mathrm{mg}$. of sodium diethyldithiocarbamate added to $3 \mathrm{ml}$. of the mixtures before the reducing agent does not result in a complete suppression of the change in viscosity but only in a very marked decrease in the rate.

Action of cuprous ion. In a mixture containing hyaluronate, cupric ions and reducing agent, cuprous ions might be the active agents in lowering viscosity. In the presence of air, saturated cuprous chloride (about 0.001 м) caused a rapid fall in the viscosity of hyaluronate; in nitrogen there was a very slight fall, but when air was subsequently admitted the viscosity fell rapidly (Fig. 6). Controls containing cupric chloride showed no fall in the presence or absence of oxygen. It seems therefore that cuprous ions together with oxygen will degrade

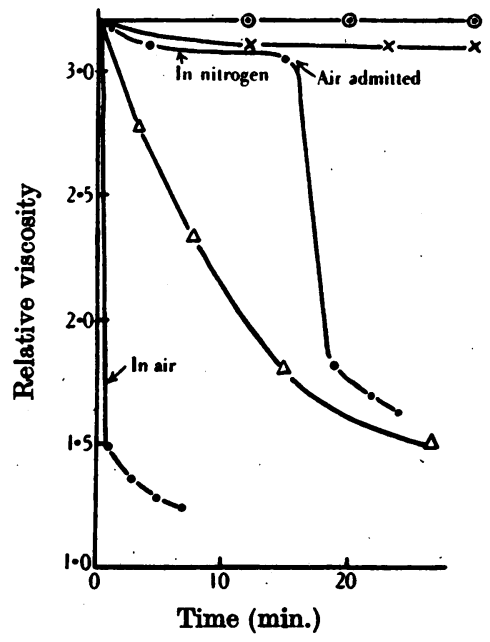

Fig. 6. Influence of oxygen on the viscosity of hyaluronate in the presence of cuprous chloride. Exp. 1. $\bullet-$ $\mathrm{Cu}_{2} \mathrm{Cl}_{2}$ saturated (about $\left.0.001 \mathrm{M}\right)(0.5 \mathrm{ml}$.); $0.1 \mathrm{M}$ buffer $(0.5 \mathrm{ml}.) ; 0.25 \% \mathrm{~K}$ hyaluronate $\left(2^{\prime} \mathrm{ml}.\right) . \odot-\odot \mathrm{CuCl}_{2}$ (0.001 M) (0.5 ml.); buffered hyaluronate solution (2.5 ml.). Exp. 2. $\odot-\odot \mathrm{CO}$ bubbled through saturated $\mathrm{Cu}_{2} \mathrm{Cl}_{2}$ solution for $1 \mathrm{hr}$. $(0.5 \mathrm{ml}$.); buffered hyaluronate solution $(2.5 \mathrm{ml}.) . \times-\times 0.25 \%$ hyaluronate $(2 \mathrm{ml}$.), and $0.1 \mathrm{M}$ buffer ( $0.5 \mathrm{ml}$.), CO bubbled through $1 \mathrm{hr}$.; before addition

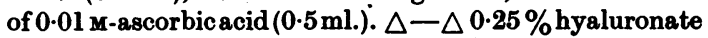
(2 ml.); $0.1 \mathrm{M}$-buffer $(0.5 \mathrm{ml}$.); $0.00 \mathrm{M}$-ascorbic acid $(0.5 \mathrm{ml}$.).

hyaluronate. Moreover, carbon monoxide which specifically combines with cuprous ions inhibits the effect. Cuprous chloride which had been exposed to carbon monoxide caused no fall in the viscosity of hyaluronate even when abundant oxygen was present.

Action of hydrogen in presence of catalytically active palladium. Hydrogen and palladium had no effect on the viscosity of hyaluronate in the absence of oxygen, but in its presence the viscosity of the hyaluronate and of starch was decreased.

The influence of phosphate. Since ascorbic acid + hydrogen peroxide will dephosphorylate $\beta$-glycerophosphate, their action on hyaluronate and other polysaccharides might be due to their action on a phosphate linkage (Robertson et al. 1941). We found that phosphorus-free hyaluronate $(P=0.002 \%$ on dry wt. of hyaluronate) was still viscous in aqueous solution and that its viscosity was decreased by exposure to ascorbic acid +oxygen (Fig. 7). The 
addition of inorganic phosphate to the reacting mixtures did not alter the rate of decrease of viscosity. It seems unlikely, therefore, that ascorbic acid + copper + oxygen lower the viscosity by dephosphorylating hyaluronate.

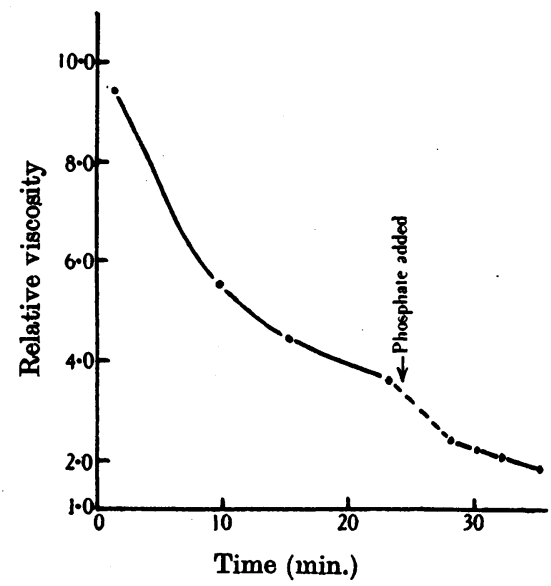

Fig. 7. Influence of phosphate on the viscosity of P-free hyaluronate in the presence of ascorbic acid. P-free hyaluronate solution $(0.5 \%)(5 \mathrm{ml}$.); ascorbic acid solution $(0.01 \mathrm{~m})$ ( $1 \mathrm{ml}$.); M-citric acid-phosphate buffer $(0.6 \mathrm{ml}$.) (pH 7.0) added at $25 \mathrm{~min}$.

Hyaluronate and the oxidation rate of ascorbic acid. The presence of hyaluronate had no influence on the rate of oxidation of ascorbic acid by oxygen.

\section{DISCUSSION}

It appears that the loss of viscosity which occurs when certain polysaccharides are exposed to the action of reducing agents takes place only when oxygen is present. Ascorbic acid, reduced phenosafranine, cuprous chloride or hydrogen must all be in a process of active oxidation in order to lower the viscosity of the polysaccharides. However, within the limits of the experimental method, potassium hyaluronate could not be shown to increase the rate of oxidation of ascorbic acid, although the polysaccharide was itself being altered. If the reducing agents used act primarily as reductants, then copper reduced to the cuprous state may be the active agent; as shown, cuprous copper with oxygen alone will produce a fall in viscosity. However, the catalytic action of copper in oxidation processes is well known, and in view of the results with ascorbic acid it seems more likely that it accelerates the polysaccharide degradation by increasing the rate of oxidation of the reducing agent. Ascorbic acid exposed to air becomes oxidized at $\mathrm{pH} \mathrm{7.0}$ in the absence of copper, and it has been shown here that sodium diethyldithiocarbamate does not completely suppress the degradation of polysaccharide by re- dacing agents. The reaction will go on very slowly in the absence of copper which, however, catalyzes it.

Apparently the sole requirement in the mixture is a reducing agent undergoing active oxidation. It is of interest that such a process is capable of initiating several diverse reactions, e.g. the ascorbic acid + hydrogen peroxide dephosphorylation of glycerophosphate (Thannhauser, Reichel \& Grattan, 1938; Robertson et al. 1941). Willison (1943) has shown that diphtheria toxin both undergoes inactivation and loses its antigenicity when exposed to sodium ascorbate when the ascorbate is undergoing reversible oxidation. The coupled oxidation of haemoglobin described by. Lemberg, Legge \& Lockwood (1939) may be a phenomenon of the same type. Lutwak-Mann (personal communication) has found that glucosamine and galactosamine, but not $\mathrm{N}$-acetylglucosamine, undergo deamination in the presence of ascorbic acid + copper.

Bawn, Hirst \& Young (1940) and Barker, Hirst \& Young (1941) have obtained evidence, by endgroup assay methods, that, in starch, the link between macromolecules, consisting of 25-30 glucose residues combined in 1:4 linkage, is a $1: 6$ glycoside linkage. If it be this link which is broken by the action of reducing agent and oxygen it is not easy to account for its instability compared with the stability of the 1:4 linkage. No evidence has yet been produced to show the nature of the linkages in hyaluronate, but it is of interest that similar reductent-oxygen systems will lower the viscosity of hyaluronate and starch. A study by end-group assay methods of the degradation products obtained by the action of reductant + oxygen systems upon these viscous polysaccharides might yield interesting results.

While this paper was being prepared for the press a communication by Skanse \& Sundblad (1943) was received. These authors describe experiments very similar to some of those reported here and obtain substantially the same results. They conclude that the depolymerization of polysaccharides in the presence of molecular oxygen, copper and reducing agents is due to oxidation of the polysaccharide molecule. They support this by showing that during the depolymerization of hyaluronic acid by hydrogen peroxide or ascorbic acid there is an increase of titratable acid groups in an amount approximately corresponding to one carboxylic group for each disaccharide-unit. They show that there is a destruction of the birefringence of flow exhibited by normal hyaluronic acid and that dialyzable substances containing nitrogen are produced. They suggest that a product of the reaction may be a disaccharide of glucuronic acid and $N$-acetylglucosaminic acid although they have not yet isolated such a compound. While they report that dehydroascorbic acid will degrade hyaluronate, they were 
unable to show that this reagent was reduced to ascorbic acid during the action. Also they show that with dehydroascorbic acid the presence of molecular oxygen is also required to accomplish the degradation of the polyseccharides. These results, together with the observed inactivity of sodium sulphate, cystine, cupric ions and oxidized thiolacetic acid reported by us, throw some doubt on their suggestion that the oxidation products of the reducing agents directly oxidize the polysaccharide.

\section{Experimental methods}

K-hyaluronate from umbilical cord (McClean, 1943) was used throughout. The material (4.1\% N) gave no biuret reaction but contained a small amount of a water-insoluble material containing iron, probably a haematin derivative (Humphrey, 1943). The polysaccharide was buffered at pH 7.0 with McIlvaine's (1921) citric acid + phosphate buffer to final conc. $M / 60$ except, where otherwise stated. Other methods employed included those for the estimation of $N$-acetylhexosamine (Morgan \& Elson, 1934), $l$-ascorbic acid (Birch, Harris \& Ray, 1933), Cu (Keilin \& Mann, 1938), $P$ (Martland \& Robison, 1926). By the term relative viscosity is meant the flow-time of the solution divided by the flow-time of water in the same Ostwald viscosimeter at $30^{\circ}$. The solution in the viscosimeter was exposed to air except when the influence of some other gas was under examination (see below).

The influence of oxygen and various $\mathrm{O} / \mathrm{R}$ dyes on lowering of viscasity. Nitrogen was passed through a series of reagents to remove oxygen in the epparatus shown in Fig. 2. A solution $(0.01 \mathrm{~m})$ of methylene blue or other dye was exactly reduced with $\mathrm{Na}_{2} \mathrm{~S}_{2} \mathrm{O}_{4}$ and $5 \mathrm{ml}$. of the reduced dye was pipetted into tube $A$ shown in Fig. 2.' Here it remained under an atmosphere of flowing nitrogen until it reached the temperature of the thermostat $\left(30^{\circ}\right)$. Meanwhile $2.5 \mathrm{ml}$. of a buffered hyaluronate solution $(0.25 \%)$ were boiled and pipetted into the viscosimeter $(B$, Fig. 2$)$ and allowed to remain under nitrogen until the temperature reached $30^{\circ}$. The reduced dye solution $(0.5 \mathrm{ml}$.) was now transferred by pipette from tube $A$ to the viscosimeter $B$ and mixed with the hyaluronate by agitating the viscosimeter. The nitrogen flow to the viscosimeter was now stopped and the mixture forced from $B$ into the viscosimeter bulb $C$ by manipulating the rubber tubes $D, E$ attached to the limbs of the viscosimeter. No reoxidation of the dye or fall in viscosity was observed during $18 \mathrm{hr}$.

The influence of catalase. Catalase was prepared from rabbit liver (Keilin \& Hartree, 1936); $0.5 \mathrm{ml}$. of the preparation liberated approx. $7 \mathrm{ml}$. $\mathrm{O}_{2} / \mathrm{min}$. from $26 \mathrm{ml}$. of $0.46 \% \mathrm{H}_{2} \mathrm{O}_{2}$ at $\mathrm{pH} 7.0$ and $16^{\circ}$. This material was used in the experiment illustrated in Fig. 4 . .

The influence of hydrogen + palladium. Hyaluronate $(4 \mathrm{ml}$. of $0.5 \%$ solution) was mixed with $1 \mathrm{ml}$. of $\mathrm{M}$-buffer at $\mathrm{pH} \mathrm{7.0}$ and $1 \mathrm{ml}$. of $1 \% \mathrm{PdCl}_{2}$. Hydrogen was bubbled through the mixture for $30 \mathrm{~min}$. The relative viscosity before hydrogen was passed was 6.6: after hydrogen was passed it was 3.5. The rate of viscosity fall became slower until mare hydrogen was passed, when the $r^{n}$,te accelerated until the relative viscosity had fallen below 2 . The $\mathrm{pH}$ at the end of the reaction was unchanged. In control experiments in which air was passed instead of hydrogen or hydrogen was used in the absence of $\mathrm{PdCl}_{2}$, no fall in viscosity was observed. Hydrogen was passed through a solution of
$\mathrm{PdCl}_{2}$, the precipitate washed with water and suspended in hyaluronate solution. No fall in viscosity occurred until hydrogen was passed, when the viscosity fell rapidly. Copper, instead of palladium, will not catalyze this reaction.

The experiment was repeated in a hydrogenation apparatus, but the amount of hydrogen taken up per unit weight of polysaccharide was variable. Therefore an experiment was performed with an oxygen-free gas phase in the viscosimeter. Nitrogen was bubbled through a solution of hyaluronate containing activated palladium. When hydrogen was passed, very little fall in viscosity occurred until air was admitted, when the fall was rapid.

Experiments in which solutions of starch replaced the hyaluronate used in the foregoing experiments showed that this polysaccharide also is degraded by palladium + hydrogen + oxygen.

The influence of phosphate. A sample of purified $\mathrm{K}$ hyaluronate (containing $\mathbf{1 . 2 5} \% \mathrm{P}$ ) after prolonged dialysis against distilled water contained only $0: 232 \% \mathrm{P}$. Bone phosphatase (5 mg.) having primary phosphatase activity and a trace only of phosphodiesterase activity was added to $105 \mathrm{ml}$. of the dialyzed hyaluronate solution ( $\mathrm{pH} \mathrm{.7 \cdot 8)}$ containing $500 \mathrm{mg}$. K-hyaluronate and $0.003 \mathrm{M}-\mathrm{MgCl}_{2}$. The mixture was incubated at $37^{\circ}$ for $6 \mathrm{hr}$. together with a control without phosphatase. After this time there was no difference in the viscosity of the two samples; both had a relative viscosity of 56 . The phosphatase-treated sample was now dialyzed against frequent changes of $0.2 \mathrm{M}-\mathrm{NaCl}$ for 3 days, after which the $P$ content was only $0.002 \%$ of the dry wt. of the hyaluronate. An indeterminable amount of this was inorganic. This phosphorus-free hyaluronate was used for the experiment illustrated in Fig. 7.

The influence of $K$-hyaluronate on the oxidation rate of ascorbic acid. A solution of hyaluronate $(0.25 \%)$ saturated with chloroform, and a similar sample of chloroform water, were kept under identical conditions at $4^{\circ}$. To $4 \mathrm{ml}$. of each were added $1 \mathrm{ml}$. of buffer and $1 \mathrm{ml}$. of ascorbic acid $(0.01 \mathrm{M})$. Both solutions were incubated at $34^{\circ}$ and a sample of the hyjaluronate + ascorbic acid mixture was observed for decrease of viscosity, which fell from 3.04 to 1.60 in $30 \mathrm{~min}$. The ascorbic acid content of both samples after this period was $0.225 \mathrm{mg}$. ascorbic acid $/ \mathrm{ml}$.

\section{SUMMARY}

1. The influence of reducing agents on the viscosity and characteristic precipitability of various polysaccharides is described.

2. Molecular oxygen is essential to the action between these polysaccharides and the reducing agents used.

3. The influence of the reducing agents + oxygen on the polysaccharides is accelerated by the presence of cupric ions. Evidence is provided that the action of copper may be due to its reduction to the cuprous state.

4. Hydrogen in the presence of catalytically active palladium + oxygen will lower the viscosity of potassium hysluronate and starch.

5. The bearing of these results on the general action of reducing agents on polysaccharides is discussed.

I wish to thank. Dr D. McClean, in whose department this work was done, and Dr H. J. Rogers, for their constant interest and advice. 


\title{
REFERENCES
}

Barker, C. C., Hirst, E. L. \& Young, G. T. (1941). Nature, Lond., 147, 296.

Barron, E. S. G., DeMeio, R.'H. \& Klemperer, F. (1935). J. biol. Chem. 112, 625.

Bawn, C. E. H., Hirst, E. L. \& Young, G. T. (1940). Trans. Faraday Soc. 36, 880.

Birch, T. W., Harris, L. J. \& Ray, S. N. (1933). Biochem. J. 27, 590 .

Humphrey, J. H. (1943). Biochem. J. 37, 460.

Keilin, D. \& Hartree, E. F. (1936). Proc. roy. Soc. B, $121 ; 173$.

- \& Mann, T. (1938). Proc, roy. Soc. B, 125, 187.

Lemberg, R., Legge, J. W. \& Lockwood, W. H. (1939). Biochem. J. 33, 754.

McClean, D. (1943). Biochem. J. 37, 169.

— \& Hale, C. W. (1940). Nature, Lond., 145, 866.
McClean, D. \& Hale, C. W. (1941). Biochem. J. 35, 159.

McIlvaine, T. C. (1921). J. biol. Chem. 49, 183.

Madinaveitia, J. \& Quibell, T. H. H. (1941). Biochem. J. $35,456$.

Martland, M. \& Robison, R. (1926). Biochem. J. $20,847$.

Morgan, W. T. J. \& Elson, L. A. (1934). Biochem. J. 28, 988.

Pirie, A. (1942). Brit. J. exp. Path. 23, 277.

Robertson, W. van B., Ropes, M. W. \& Bauer, W. (1940). J. biol. Chem. 133, 261.

- (1941). Biochem. J. 35, 903.

Seshagirirao, P. \& Giri, K. V. (1942). Proc. Indian Acad. Sci. Bangalore, $16 \mathrm{~B}, 190$.

Skanse, B. \& Sundblad, L. (1943). Acta phys. Scand. 6, 37.

Thannhauser, S. J., Reichel, M. \& Grattan, J. F. (1938). Biochem. J. 82, 1163.

Willison, F. E. (1943). J. Immunol. 47, 409.

\section{Studies on Diffusing Factors}

\section{THE INFLUENCE OF SOME ENVIRONMENTAL CONDITIONS ON THE ACTIVITY OF HYALURONIDASE}

\author{
By C. W. HALE, The Lister Institute of Preventive Medicine, Elstree, Herts
}

(Received 19 February 1944)

In the course of other work (Hale, 1944), observa. tions were made to determine whether reducing agents or other substances which.affect the viscosity of hyaluronic acid also exert any influence on the activity of hyaluronidase.

\section{METHODS}

The methods used were those described previously (McClean \& Hale, 1941; McClean, 1943; Hale, 1944).

\section{RESULTS}

Influence of oxygen on hyaluronidase activity. Ex. periments were carried out in the viscosimeter apparatus described by Hale (1944). There was no significant difference in the activity of the enzyme under any of the conditions shown in Table 1 . It is concluded that the enzyme does not need molecular oxygen for its activity, nor does the enzyme during its action on the substrate at $\mathrm{pH} 7 \cdot 0$ produce conditions which will either oxidize reduced rosinduline or reduce indophenol. The activity of the enzyme is not readily affected by exposure to oxygen.

Influence of $\mathrm{Cu}$ and $\mathrm{Na}$ diethyldithiocarbamate on hyaluronidase. Since $\mathrm{Cu}$ increases the rate of reaction in a reductant + oxygen + hyaluronate mixture it was thought that it might have a similar action upon hyaluronidase + hyaluronate. Copper (0.1 mg.

\section{Table 1. The influence of oxygen on hyaluronidase activity}

(The enzyme + substrate mixture had the following composition :

$2.0 \mathrm{ml}$. K-hyaluronate $(0.25 \%)$ previously boiled

$0.5 \mathrm{ml}$. McIlvaine's buffer (pH 7.0) $\}^{2}$ and cooled.

$0.5 \mathrm{ml}$. crude $\mathrm{Cl}$. welchii hyaluronidase $(1: 100$ in boiled and cooled water).

Temperature of thermostat $30^{\circ}$.

Rosinduline, exactly reduced with $\mathrm{Na}_{2} \mathrm{~S}_{2} \mathrm{O}_{4}$, included as a reducing agent and as an indicator of oxidation.

Indophenol added as an indicator of reduction.)

$\begin{array}{lcc}\begin{array}{c}\text { Conditions } \\ \text { In nitrogen + trace of } \\ \text { reduced rosinduline }\end{array} & \begin{array}{c}\text { v.R.v.* } \\ \text { activity }\end{array} & \begin{array}{c}\text { Remarks } \\ \text { Rosinduline not } \\ \text { re-oxidized }\end{array} \\ \begin{array}{ccc}\text { In nitrogen + trace of } \\ \text { indophenol }\end{array} & 105 & \begin{array}{c}\text { Indophenol not } \\ \text { reduced }\end{array} \\ \text { In air; no dye } & 108 & - \\ \text { ", } & 96 & - \\ \text { In oxygen; enzyme } & 95 & - \\ \text { and substrate satu- } & & \\ \text { rated with oxygen } & & \\ \text { * v.R.U. = viscosity reducing units (McClean, 1943). }\end{array}$

as sulphate) was added to $2 \mathrm{ml}$. hyaluronate $(0.25 \%)+0.5 \mathrm{ml}$. of $0.1 \mathrm{~m}$-McIlvaine's buffer ( $\mathrm{pH}$ $7 \cdot 0)+0.5 \mathrm{ml}$. Cl. welchii hyaluronidase dilution, 